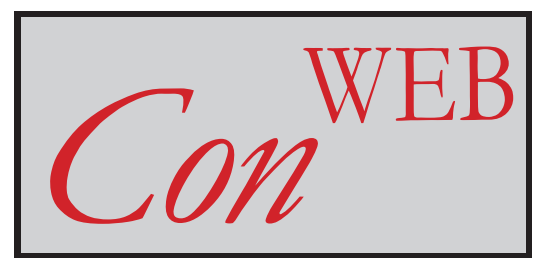

Webpapers on

Constitutionalism \& Governance beyond the State

Year 2005 | No 5

The Neofunctionalists Were (almost) Right: Politicization and European Integration

Lisbet Hooghe and Gary Marks

ISSN: $1756-7556$

conWEB - webpapers on Constitutionalism and Governance beyond the State www.bath.ac.uk/esml/conWEB 
Constitutionalism Web-Papers, ConWEB No. 5/2005

The Neofunctionalists Were (almost) Right: Politicization and European Integration

Lisbet Hooghe* (hooghe@,unc.edu)

Gary Marks** (marks@unc.edu)

\begin{abstract}
This paper examines the politicization of European integration. We begin by asking how neofunctionalism and its precursor, functionalism, conceive the politics of regional integration. Then we turn to the evidence of the past two decades and ask how politicization has, in fact, shaped the level, scope, and character of European integration.
\end{abstract}

\title{
Keywords
}

political science, integration theory, neo-functionalism, identity, multi-level governance

Associate Professor of Political Science, University of North Carolina at Chapel Hill, and Professor, Chair in Multi-level Governance, Free University of Amsterdam.

** Burton Craige Professor of Political Science, University of North Carolina at Chapel Hill, and Professor, Chair in Multi-level Governance, Free University of Amsterdam. 
In a recent paper, Philippe Schmitter laments that "no theory of regional integration has been as misunderstood, caricatured, pilloried, proven wrong and rejected as often as neofunctionalism" (2002:1). And he goes on to explicate, embrace, and elaborate neofunctionalism in his inimitable way. Almost fifty years of neofunctionalism have taught us a thing or two about regional integration. Neofunctionalism identifies basic building blocs for any valid theory of the subject, and more generally, for any valid theory of jurisdictional architecture.

Neofunctionalism argues that regional integration is shaped by its functional consequences - the pareto gains accruing to integration-but that functional needs alone cannot explain integration. Regional integration gives rise to potent political tensions. It shakes up relative capabilities, creates new inequalities, and transforms preferences. Above all, it leads to politicization, a general term for the process by which the political conflicts unleashed by integration come back to shape it. Neofunctionalists recognize that a decisive limitation of functionalism is that it does not engage the political consequences of its own potential success. What happens when the "objects" of regional integration-citizens and political parties — wake up and became its arbiters?

In this essay, we begin by taking a close look at how neofunctionalism and its precursor, functionalism, conceive the politics of regional integration. Then we turn to the evidence of the past two decades and ask how politicization has shaped the level, scope, and character of European integration.

\section{FUNCTIONALITY AND POLITICS}

Neofunctionalism's point of departure is that functional efficiency is the engine of regional integration. The functional premise remains a vital one in regional integration theory. It grounds Wayne Sandholtz' and Alec Stone Sweet's transactionalist theory of supranational governance (1998; Sweet, Sandholtz, and Fligstein 2001), Mark Pollack's application of principal-agent theory to the European Union (2003), and Andrew Moravcsik's liberal institutionalist account of EU treaty making (1998).

Functionalism identifies a rational basis for political choice. Welfare gains or lossesMitrany's “common index of need" (1966: 159)—determine whether a particular policy will, or will not, be selected. Neofunctionalists counter that functional pressures are necessary, but not sufficient, to change the scope, level, or character of regional integration. They conceptualize three intervening processes. Functional spillover occurs when an original 
integrative goal can be assured only by integration in a functionally related area. Externalization describes the pressure on the members of a regional regime to adopt a single, and therefore integrative, policy towards third parties. And most importantly, politicization describes a process by which regional integration becomes contested among a widening circle of political actors (Schmitter 1969).

This stands in stark contrast to functional theory. Functionalism assumes the "inevitability of socio-economic gradualism and the supremacy of welfare and technology over power politics" (Pentland 1975: 9). Functional needs are presumed to have self-evident consequences for the scope, level, and character of regional organization. As integration bears fruit, so experts and beneficiaries learn that integration can effectively be extended to other practical, non-controversial needs. But there is a certain automaticity to the process. Hard political choices, political mobilization, and above all, conflict, are irrelevant or harmful. David Mitrany argued that successful integration requires consensus about practical goals and abstinence from power politics. As James Caporaso points out, "Functionalists . . . believe in the possibility of defining certain nonpolitical aspects of human needs, nonpolitical in the sense that there is a high level of consensus concerning them. Such areas are labeled 'technical' or 'welfare-oriented.' . . The end result would be a community in which interest and activity are congruent and in which politics is replaced by problem-solving" (1972: 27).

Politicization is the point at which functionalists and neofunctionalists part company. For Ernst Haas, Leon Lindberg, and the early Philippe Schmitter, politics is not a drag on regional integration, but an essential ingredient. Haas' Uniting of Europe: political, social and economic forces, 1950-1957 is a study of political calculation-of "nationally constituted groups with specific interests and aims, willing and able to adjust their aspirations by turning to supranational means when this course appears profitable" (1958: xiv). Schmitter argues that, "alone, functional interdependence based on high rates of mutual transactions is impotent. It must be perceived, interpreted, and translated into expressions of interest, strategies of influence, and viable decision making styles" (1969: 164). Functionality-the pareto gains accruing from integration - is the engine, but politicization is the drive shaft-a decisive intervening variable-determining whether, when, and how functional pressures lead to regional integration.

At its core, politicization refers to the increasing contentiousness of decision making. According to Philippe Schmitter, "Politicization . . . refers initially to a process whereby a) the controversiality of joint decision making goes up. This in turn is likely to lead to $b$ ) a widening of the audience or clientele interested and active in integration. Somewhere along 
the line c) a manifest redefinition of mutual objectives will probably occur. . . . It . . involves some collective recognition that the original objectives have been attained . . . and that the new ones involving an upward shift in either scope or level of commitment are operative. Ultimately, one could hypothesize that . . . there will be $d$ ) a shift in actor expectations and loyalty toward the new regional center" (1969: 166. Italics in original; alphabetization added).

The early neofunctionalists were sanguine that politicization would raise the level and extend the scope of regional integration. A federal polity, or something like it, would result. Haas described the European Economic Community in 1958 as a "new centre, whose institutions possess or demand jurisdiction over the pre-existing ones" (1958: 16). He argued that "even though supranationality in practice has developed into a hybrid in which neither the federal nor the intergovernmental tendency has clearly triumphed, these relationships have sufficed to create expectations and shape attitudes which will undoubtedly work themselves out in the direction of more integration" (1958: 526-7; our emphasis). But as early as 1969, Schmitter was at pains to assume no automaticity, fixed sequence, or unidirectionality (1969, 1970). Reflecting on the original research program three decades later, he stresses that neofunctionalists had too rosy a view of the transformation of governance, and notes that "any comprehensive theory of integration should potentially be a theory of disintegration" (2002: 2).

So regional integration can contract as well as expand. Haas, Lindberg, and others began also to doubt their initial prediction of a single end-point, a European federation, and conceived of several possible outcomes. In a provocative piece initially written just after the Maastricht negotiations, Philippe Schmitter conceptualized non-state scenarios characterized by growing dissociation between territorial constituencies and functional competencies (1996; see also 2003: 15). Ironically, given their differences, neofunctionalists and functionalists converge in their speculations about the jurisdictional architecture of integration. Mitrany was a passionate opponent of federalism, which he felt was inappropriately rigid (1948, reprinted in 1966). Philippe Schmitter is skeptical of federal schemes for Europe, "because, in the immediate future, the Europolity is likely to retain the status of a 'nonstate and nonnation'-it would be inappropriate and even counterproductive to define its citizens, representatives, and rulers in the usual manners for a large-scale, socially heterogeneous, advanced capitalist nation-state, that is, in the manner of a federal polity" (2000: 15). The most extreme non-state scenario conceptualized by Philippe Schmitter-condominio (1996)—shares some basic features with David Mitrany's functional vision. The European polity has no fixed center, but is a network of jurisdictions with variable membership, variable decision rules, and of 
variable durability, depending on need and acceptability. These features, we will argue, are strengthened by politicization.

\section{THE STRUCTURE OF POLITICAL CONFLICT}

Neofunctionalism kicked off a thirty-year research program analyzing politicization in the European Union (Lindberg and Scheingold 1970). In this period, one neofunctionalist prediction has come to pass: European integration has become more controversial, as Philippe Schmitter foresaw. What few predicted is that the sign would be negative.

Support for European integration among the public has not risen, and in some countries has declined, since the early 1990's (Eichenberg and Dalton 1993, 2003; Franklin, McLaren and Marsh 1994). Elites were always likely to be more favorably oriented to integration than the public as a whole; a fact that has become politically combustible as European integration has instigated 28 national referenda in 17 member and candidate countries. ${ }^{1}$ In short, Leon Lindberg's permissive consensus has been transformed into something approximating its opposite, a constraining dissensus (Olsen 2004; Hix 1999; Hooghe and Marks 1999; van der Eijk and Franklin 1996; Marks and Steenbergen 2004; Niedermayer and Sinnott eds. 1995).

At the same time, the interested audience has widened, again as predicted by neofunctionalists. The mobilization of interest groups, social movements, unions, firms, and subnational governments at the European level has generated a broad stream of research substantiating the neofunctionalist expectation that, "Once a regional integration scheme is established, it may serve as the stimulus for private groups to create . . regional organizations to reflect and protect their common interests ..." (Nye 1970: 205; Imig and Tarrow 2001; Marks, Haesly, and Mbaye 2002; Marks and McAdam 1996; Mazey and Richardson 2001; Streeck and Schmitter 1991; Wessels 2004). The issues arising from European integration reach deeply into political parties - the primary aggregators of political interests in European democracies_-and into the public itself.

Even in the early days, neofunctionalists were alert to the fact that domestic conflict about European integration could stretch beyond sectoral or business associations. Ernst Haas

1 This includes ten referenda in 2004 accession countries. It does not include anticipated referenda on the European Constitutional Treaty. As of April 9, 2005, nine countries (the Czech republic, Denmark, France, Ireland, Luxembourg, the Netherlands, Portugal, Spain, and the United Kingdom) had held or were going to have referenda. Source: Centre d'études et de documentation sur la démocratie directe in Geneva, Switzerland (http://c2d.unige.ch/, accessed April 9, 2005). 
stressed that sectoral associations leant heavily on their national governments where their particular economic interests were concerned-a line of analysis that was later taken up by intergovernmentalists - but he was also keenly aware that political parties were decisive both for the creation of a coherent Euro-polity and because, in Europe, government is party government. In The Uniting of Europe (1958), Haas begins by describing in detail the positioning of political parties in the major party families, and moves on to national trade associations, trade unions, and national governments.

The difference now is that decision making on the big issues has shifted away from iron triangles of producers to national contests which, in an increasing number of cases, involve national referenda. The positioning of political parties and of citizens has, since the Maastricht Accord, grown in relative importance while that of sectoral associations has declined.

How, then, does conflict over European integration connect to the dimensions that structure public opinion and competition among political parties? The first of these dimensions is an economic Left/Right dimension concerned with economic redistribution, welfare, and government regulation of the economy. Contestation on this dimension has predominated in most Western nations in the postwar period (Bartolini and Mair 1990; Lipset and Rokkan 1967), and is diagnosed as the main dimension in Central and Eastern Europe (Evans and Whitefield 1993; Kitschelt et al. 1999). A second, non-economic or cultural, new politics dimension has gained strength since the 1970s in Europe - in the East as well as in the West (Evans and Whitefield 1993; Flanagan 1987; Franklin 1992; Inglehart 1977; Kitschelt 1995). In some societies this dimension is oriented around environmental protection; in others, it captures conflict about traditional values rooted in a secular/religious divide; in yet others, it is pitched around immigration and defense of the national community. We therefore describe the poles of this dimension with composite terms: Green/Alternative/Libertarian (or Gal) and Traditionalist/Authoritarian /Nationalist (or Tan) (Hooghe, Marks, Wilson 2002).

\section{$\underline{\text { Left/Right }}$}

When EU issues have distributional economic effects within societies - as is clearly the case for social policy, employment policy, and above all, for policies that reduce the transaction costs of international economic exchange- the positions that political parties take can be predicted from their left/right location. 
Table 1: Left/right Positioning and Position on Economic EU Policies (correlations)

\begin{tabular}{lc}
\hline Internal Market & 0.34 \\
Employment & -0.53 \\
Cohesion & -0.25 \\
General Position & 0.04 \\
\hline
\end{tabular}

Note: Data from the Chapel Hill 2002 party expert dataset, tapping 238 country experts to evaluate the ideological and EU policy locations of 98 political parties in the West (EU-15 minus Luxembourg). Experts locate parties on a scale from 1 (strongly opposed) to 7 (strongly favoring). Parties weighted by vote percentage in most recent national election.

Internal Market: "Consider internal market liberalization. Some parties want to strengthen EU powers in the internal market and competition policy. Other parties are reluctant to support stronger EU powers for internal market liberalization."

Employment: "Consider EU employment policy. Some political parties want the EU to strengthen its common employment policy; they view EU employment policy as a means toward reducing unemployment. Other parties argue against a common employment policy."

Cohesion: "Consider EU cohesion or regional policy. This policy transfers resources to the poorest regions in the EU, and is the second item on the EU budget. Some political parties wish to maintain or expand the EU's cohesion policy, whereas others wish to reduce or eliminate it."

General Position: "How would you describe the general position to European integration that the party's leadership has taken over the course of 2002?"

To return to the level/scope distinction, distributional politics directly engages the scope, but not the level of integration. Should the European Union spend money to diminish unemployment, aid poorer regions, or promote social cohesion? The debate is about for whom, from whom, and how much; it is not intrinsically about by whom. Simon Hix, Mark Pollack and others have pointed out that left/right speaks to supranationalism with many voices (Hix 1999; Pollack 2000). The logic, as in the United States, is one of "regime shopping" When liberals were ascendant at the federal level of the United States, conservatives found themselves convinced of the virtue of states rights. Now that conservatives are ascendant, it is the liberals' turn. What matters is the structure of political opportunity as it exists in a particular time and place.

In the context of the EU, the economic right is satisfied with the combination of market integration and nationally segmented political authority. Market integration involves the creation of a single market, a transnational goal that demands limited supranational authority. Neoliberals support European institutions, and the European Court of Justice in particular, when they limit national regulation- "negative" integration (Scharpf 1996). So those on the economic right see the virtues of raising the level of integration, of central control over the distributional capacity of national states. But it would be self-defeating for 
neoliberals to extend the scope of integration in ways that would diminish regulatory competition.

Those on the economic left wish to create redistributive capacity at the European level, but they do not want to constrain redistribution and other social democratic policies at the national level. Left parties were the chief concern of early integrators, including Jean Monnet, who realized that such parties might resist functional economic integration on distributional grounds. Monnet made every effort to persuade socialist party and trade union leaders that European integration deserved their support. By the late 1950s, Ernst Haas identified a "sinistration" of support for a federal Europe (1958: xiv). But the debate on European integration was still raging among French and British socialists in the early 1980s. Most socialists eventually came to the conclusion that if exit was impossible, they should try to extend the scope of integration to include the distributional policies that were in Jacques Delors' vision.

We detected this in the mid-1990s (Hooghe and Marks 1996, 1999), but in the meantime the left's enthusiasm for the Delors project of regulated capitalism has cooled. Although European political economies are more welfare oriented and redistributive than the US, they vary in ways that make convergence on a single European model the least likely of future scenarios. Institutional variation across the EU sharply constrains the feasible scope of continent-wide regulation. Step by step integration - the (neo)functional recipe - is inhibited by country-specific institutional complementarities among institutions responsible for economic governance (Crouch and Streeck 1997; Streeck 1996; Hall and Soskice 2001). ${ }^{2}$ Moreover, institutional differences exist within, as well as among, countries that are said to have a particular type of governance. Denmark, for example, finances its welfare state primarily through income taxation, while Sweden relies to a much greater extent on social security contributions, a contrast that would complicate integration of these social democratic welfare regimes (Scharpf 1999).

Moreover, social democrats have become acutely aware that redistribution is constrained by cultural diversity (Offe 2000). The relationship can be hypothesized as a "law" of culturally constrained redistribution: the more culturally diverse a polity, the smaller the scope for redistribution. At one end of the scale are encompassing global organizations,

2 Fritz Scharpf makes the point that preferences differ across countries in ways that decisively constrain integration. He observes that British would revolt against the high taxes that sustain the generous Swedish welfare state, that Swedes would not settle for a poorly funded educational system as in Germany; and that German doctors and patients would protest against attempts to emulate the British national health system (Scharpf 2001). 
including the UN, the World Bank, and the WTO, that redistribute at most a tiny fraction of global GDP. At the other extreme are relatively homogenous national polities, which redistribute up to about one third of the national product. While the European Union is more culturally coherent than most other international regimes, it is considerably more diverse that the most diverse federal states. No other international or transnational regime redistributes anything like the 0.8 percent of GDP that the EU devotes to agricultural and cohesion funding. Because a shared sense of community is lacking in Europe, it is difficult for social democrats to campaign for more.

Given that neither the left nor the right has managed to achieve durable political hegemony at the continental level, and given high decisional barriers for institutional innovation, the struggle over economic redistribution has not done much to deepen integration. $^{3}$

The main thrust of integration has been functional, not redistributive. The scope and level of regional integration in Europe has been constrained by the area of agreement between center left and center right on the collective benefits of internal peace and transnational economic exchange. European integration has largely followed the prescriptions of classical federalism: a) centralize those areas of public policy where economies of scale are present; $b$ ) internalize positive and negative externalities by encompassing in the relevant jurisdiction all those affected by the policy; c) otherwise, decentralize.

Does this mean that left/right conflict has no bearing on European integration? Not quite. Functionalism is opaque. What does "affected by the policy" mean? Was slavery in the South an externality for those in the North of the United States? Does the denial of equal pay for women, or of political rights for immigrants, in one part of the Union "affect" citizens in another part? This invites a debate about the implications of cohesion in a political community, a debate that is fundamental to the left/right divide. The front line of redistributional conflict in the EU is in the application of European-wide regulation in areas such as social policy and environmental policy (Caporaso 2000; Falkner 1998; Leibfried and Pierson ed. 1995; Sbragia 1996).

So the conclusion to this section is double-edged. Distributional conflict has not driven regional integration forward. But social regulation (with distributional consequences) is an ineluctable tension in regional integration. Functionalism cannot arbitrate conflict about the

3 It therefore comes as no surprise that left/right only weakly frames public opinion on European integration. A variable that taps left/right self placement is significant under controls if allowance is made (via an interaction term) for the fact that in Scandinavia, in contrast to the rest of the EU, it is the left, not the right, that is more opposed to integration. But the size of the effect is small (Hooghe and Marks 2004). 
allocation of authority in a multi-level polity. The struggle between left and right about social regulation leads to unstable and contested outcomes about the scope of policy, in which the level of policy - the degree of supranationalism - is a by-product reflecting which side happens to have authority at which level.

\section{Identity}

Functionalists and neofunctionalists alike stressed the constraining effects of national identity on integration. "We are favored by the need and the habit of material cooperation; we are hampered by the general clinging to political segregation. How to reconcile these two trends, both of them natural and both of them active, is the main problem for political invention at this juncture of history" (Mitrany 1948 [1966]: 151). But functionalists and neofunctionalists believed that national identity would ultimately give way to a more encompassing loyalty. According to Mitrany, national identity is just one, and not the most important kind of identity: "Each of us is in fact a bundle of functional loyalties; so that to build a world community upon such a conception is merely to extend and consolidate it also between national societies and groups" (1965 [1966]: 204). In one of the first analyses of public opinion on European integration, Ronald Inglehart predicted that a shift of loyalties was a matter of generational replacement. Younger cohorts, he argued, were being socialized in societies where nationalism was discredited and where supranational institutions were providing an expanding range of collective goods (Inglehart 1970: 182-190).

Recent research arrives at a different verdict: national identity remains a supremely powerful constraint on preferences concerning the level of European integration (Carey 2002; Hooghe and Marks 2004; McLaren 2002; Hermann, Brewer, Risse eds. 2004). This is true both for political parties and for the general public.

As noted above, national identity connects to the second dimension of conflict across western societies, which we describe as a Green/Alternative/Libertarian (or Gal) versus Traditionalist/Authoritarian/Nationalist (or Tan) dimension.

The position of a political party on the Gal/Tan dimension powerfully predicts its position on European issues that engage the level of integration. So, as Table 2 reveals, party location on Gal/Tan is strongly associated with positioning on European integration in general and on the powers of the European Parliament. The association is anchored on the right side of this dimension by parties with a strong Tan leaning-e.g. the Front National, Vlaams Blok/Belang, Austrian Freiheitlichepartei, and Danske Folkspartiet. This is a relatively new phenomenon. In 1984, the first year for which we have data on party positioning, the main 
source of opposition to European integration came from social democratic parties. Not until the mid-1990s was the largest reservoir of opposition on the radical right (Hooghe, Marks, Wilson 2002; Taggart 1998). Such parties oppose integration because it undermines national sovereignty. They link European integration to other perceived threats to the national community: foreign cultural influences, cosmopolitan elites, international agencies, and above all, immigrants.

Table 2: Gal/Tan Positioning and Position on Institutional EU Policies (correlations)

\begin{tabular}{lcc}
\hline & West & East \\
\hline EP Powers & -0.50 & -0.57 \\
Enlargement & -0.38 & -0.71 \\
General Position & -0.30 & -0.65 \\
\hline
\end{tabular}

Note: Data from the 2002 Chapel Hill party expert dataset, tapping 238 country experts to evaluate the ideological and EU policy locations of 98 political parties in the West (EU-15 minus Luxembourg) and 73 in the East (EU-10 minus Cyprus, Estonia and Malta). Experts locate parties on a scale from 1 (strongly opposed) to 7 (strongly favoring). Parties weighted by vote percentage in most recent national election.

EP Powers: "Take the position of the party leadership on the powers of the European Parliament. Some parties want more powers for the European Parliament. Other parties argue there is no need to expand the powers of the European Parliament further."

Enlargement (West): "Consider enlargement to Central- and Eastern European countries. Some parties believe that the new countries should have exactly the same rights and duties as existing members. Others believe there should be separate rules for them (e.g. on agricultural policy, cohesion policy, internal market, movement of people, currency)."

Enlargement (East): "Consider EU enlargement to the candidate countries of postcommunist Europe. Some parties strongly support major domestic reforms to qualify for EU membership as soon as possible. Other parties oppose major domestic reforms to qualify for EU membership as soon as possible." General Position: "How would you describe the general position to European integration that the party's leadership has taken over the course of 2002?"

National identity also mobilizes Euroskepticism in conservative parties with a national character-as in Britain, France, Ireland, and Spain. Conservative parties in these countries combine defense of the national community with support for market solutions. European integration puts these in tension, and fuels conflict between market liberals, who are willing to water down national sovereignty in the cause of market competition, and nation-oriented traditionalists, who are not. The result is internal party dissension that in some cases - the British Conservatives and the French Gaullists- has threatened to tear these parties apart.

By the mid-1990s, the political mobilization of national identity led to the "dextrification" of opposition to European integration. Enlargement to Central- and Eastern Europe has reinforced-not weakened-this. The strongest opposition to European 
integration in Central and Eastern, as in Western Europe, is found among parties that espouse traditionalist, nation-centered ideologies (Marks et al. 2004).

National identity also constrains public opinion on European integration, but in a double-edged way. On the one hand, national identity and European identity reinforce each other. In his dissertation on the topic, Richard Haesly (2001) finds a positive, rather than negative, association between being Welsh or Scottish and European. European allegiance can fruitfully be conceived as embedded in national allegiance (van Kersbergen 2000).

But it is also true that many opponents of European integration see themselves as defending their nations against control from Brussels. Diez Medrano details how national histories condition the consequences of national identity for support for European integration: English Euroskepticism is rooted in Britain's special history of empire, West German proEuropeanism reflects Second World War guilt; the Spanish tend to support European integration as proxy for modernization and democratization (2003; see also Stråth and Triandafyllidou 2003).

National identities are formed early in life, as Inglehart recognized in his 1970 piece. Children as young as six or seven know full well whether they are English, German, or Swedish. But the impact of identity on political attitudes is neither automatic nor uniform. The connection between a person's identity and her attitude toward European integration is constructed in political debate, and that construction is cued by national political parties, national elites, and national media. Where the political elite is more or less united on Europe, national identity and European integration tend to coexist; where it is divided, national identity feeds Euroskepticism (Hooghe and Marks 2004).

Neofunctionalists recognized that regional integration had to be understood as a broadly-based political process that engaged a variety of domestic actors, not just national governments. The history of European integration since the tumultuous reception of the Maastricht Accord in 1992 has confirmed this insight. But did neofunctionalists get the sign of the effect right? ${ }^{4}$

If one were to extrapolate the experience of contestation over redistribution and identity described above, one would be compelled to answer "no." Politicization appears to be - at least at this point in history—neither positive, nor open-ended, with respect to regional

\footnotetext{
4 In a recent publication, Philippe Schmitter acknowledges that neofunctionalist theory underestimated the enduring character of national identity and its constraining effect on European integration (2002). As we have noted, this criticism is least appropriate for Schmitter's own work.
} 
integration. If recent research is valid, politicization is powerfully shaped by nationalist reaction against perceived loss of community and national sovereignty.

In retrospect, it seems unexceptional that a quantum shift in authority — which is, after all, what sixty years of European integration adds up to-should jolt nationally embedded emotions. A student of modern European history might heed a simple warning: "Never underestimate nationalism." Group attachments can be extraordinarily powerful, and few more so than attachments to territorially-defined communities. The mobilization of exclusive national identity in defense of national sovereignty is therefore a predictable reaction to Europeanization.

Neofunctionalists and functionalists feared as much, and they urged a course of incremental steps that would lead Europe around, not through, national identity. This was the guiding principle of the Monnet method, a neofunctionalist strategy prior to the theory (Duchêne 1994). Mitrany believed that the creation of multiple functional regimes would defuse nationalist reaction, that it was better that authority seep away from national states in several directions, rather than to a single new center.

\section{POLITICIZATION AND THE FORM OF MULTI-LEVEL GOVERNANCE}

The politicization of integration, and in particular the mobilization of national identity, has constrained European political architecture. The functional logic of regional integration is as strong as it ever was, but the institutional strategy is changing. Instead of bundling an ever more extensive set of policies in a coherent European federal polity - a common set of policies for a given territory-we have seen a growing dissociation between territory and function. The result is a system of multi-level governance which takes on the characteristics of a consortio modified by growing reliance on condominio.

Practicing neofunctionalists, including Jean Monnet, conceived their challenge to be building Europe in the absence of Europeans. They believed that Europeans could be created indirectly, as citizens felt the policy effects of regional integration, and transferred their loyalties accordingly. Regional integration was to be built piecemeal, in the confident expectation that the emergent polity would be considered legitimate. Their strategy was to shift an ever wider set of competencies from national states to Europe. Each act of integration was justified in its own terms, but the effect was to transform European political architecture in a federal direction. This strategy survived Charles de Gaulle in the 1960s and Margaret 
Thatcher in the 1980s. These leaders rejected supranationalism, but accepted the logic of piecemeal integration where justified on efficiency grounds.

From a functionalist standpoint, a federal Euro-stato would be a king with no functional clothes - as Mitrany wrote in a blistering critique of Walter Hallstein's federal plans (Mitrany 1965). A European federation was a political goal cherished by postwar elites who contended with the absence of Europeans. In more recent times, reformers have had to confront, in addition, the presence of populist nationalism. No major policy area has escaped Europeanization to some degree, but domestic support for European supranationalism is as weak as it has ever been. Enlargement to Central and Eastern Europe appears to have hardened rather than softened the edge of national opposition, as one might expect in countries that have been denied independence for so long (Taggart and Sczerbiak 2004). At the extreme, minorities in several EU member states appear willing to sacrifice functional benefits of cooperation on the altar of national sovereignty. While their numbers are proportionately low, they threaten to take political advantage of the gap that exists in every EU society between Europhile elites and a more skeptical public. The nationalist right appears most threatening in referenda, which ironically enough, constitute the most important institutional innovation in domestic liberal polities occasioned by European integration.

How can one reap the collective gains of transnational cooperation without running foul of national identity? This is the challenge for elites seeking to safeguard the functional benefits of cooperation (Hooghe 2003). Their answer appears consistent with the following principles: ${ }^{5}$

- Focus on policy problems for which decision making can convey transparent benefits to stakeholders.

- Splice policy problems into discrete chunks. Minimize policy externalities; maximize decomposability.

- Tailor decision rules to the particular task at hand.

- To the extent that pareto optimal solutions involve redistribution, pick problems where side-payments are feasible.

What kind of polity would emerge if cooperation on certain functions was desirable, but member states tailored it to the problem rather than to existing European institutions? Independent European agencies for, among others things, aviation, drug addiction, the

5 Elsewhere we describe this as Type 2 governance, oriented around task-specific jurisdictions, which can be contrasted with Type 1 governance, oriented around general-purpose jurisdictions (Hooghe and Marks 2003). 
environment, food safety, maritime safety, medical product evaluation, satellites, training, work safety and health, and vocational training are examples. And what if certain forms of integration were considered efficient for some member states, but not for others? This question was raised sharply for monetary union and for social policy, and the institutional solution has been to allow individual member states to derogate, i.e. opt out, if they so wish.

Philippe Schmitter, who saw more clearly than any of his contemporaries the storm gathering over Maastricht, speculated about the form that regional integration might be taking. "What if either the functional or the territorial domains (and even more if both) were not congruent with the same authority?" (1996: 132). Schmitter diagnosed three alternatives to a federal state. A confederatio is a loose arrangement in which territorial units may enter or exit at will but where functional competencies are rigorously fixed in order to protect members from encroachment by central authorities. In a consortio a fixed number of national authorities cooperate on a variety of functional tasks through specific, flexible, and overlapping institutional arrangements. And finally "the most unprecedented, even unimaginable, outcome of all" (136) is the condominio, where both territorial units and functional tasks vary to create multiple specialized, flexible, and overlapping regimes. "Instead of one Europe with recognized and contiguous boundaries, there would be many Europes. Instead of a Eurocracy accumulating organizationally distinct but politically coordinated tasks around a single center, there could be multiple regional institutions acting autonomously to solve common problems and produce different public goods" (136).

\section{References}

Bartolini, Stefano and Peter Mair. 1990. Identity, Competition, and Electoral Availability: The Stabilization of the European Electorate, 1885-1985. Cambridge: Cambridge University Press.

Caporaso, James A. 1972. Functionalism and Regional Integration: A Logical and Empirical Assessment. Beverly Hills: Sage Professional Paper in the International Studies Series.

Caporaso, James A. 2000. The European Union: Dilemmas of Regional Integration. Boulder, Co.: Westview Press.

Carey, Sean. 2002. "Undivided Loyalties: Is National Identity an Obstacle to European Integration?" European Union Politics 3: 387-413.

Crouch, Colin, and Wolfgang Streeck eds. 1997. The Political Economy of Modern Capitalism: Mapping Convergence and Diversity. London: Sage.

Diez Medrano, Juan. 2003. Framing Europe: Attitudes to European Integration in Germany, Spain, and the United Kingdom. Princeton: Princeton University Press. 
Duchêne, François. 1994. Jean Monnet: The First Statesman of Interdependence. New York/ London: Norton.

Eichenberg, Richard C. \& Russell J. Dalton. 1993 "Europeans and the European Community: The Dynamics of Public Support for European Integration." International Organization 47: 507-534.

Eichenberg, Richard C. \& Russell J. Dalton. 2003. "Post-Maastricht Blues: The Welfare State and the Transformation of Citizen Support for European Integration, 1973-2002." Unpublished manuscript.

Evans, Geoffrey, and Stephen Whitefield. 1993. "Identifying the Bases of Party Competition in Eastern Europe." British Journal of Political Science 23: 521-548.

Falkner, Gerda. 1998. EU Social Policy in the 1990s: Towards a Corporatist Policy Community. London: Routledge.

Flanagan, Scott C. 1987. "Value Change in Industrial Societies." American Political Science Review 81: 1303-1318.

Franklin, Mark N. 1992. "The Decline of Cleavage Politics.” In Electoral Change: Responses to Evolving Social and Attitudinal Structures in Western Europe, edited by Mark Franklin et al. Cambridge: Cambridge University Press, 383-405.

Franklin, Mark, Michael Marsh, and Lauren McLaren. 1994. "Uncorking the Bottle: Popular Opposition to European Unification in the Wake of Maastricht." Journal of Common Market Studies 32: 455-72.

Groom, A.J.R. and Paul Taylor eds. 1975. Functionalism: Theory and Practice in International Relations. London: University of London Press.

Haas, Ernst B. 1958. The Uniting of Europe. Stanford: Stanford University Press.

Haas, Ernst B. 1961. "International Integration: The European and the Universal Process." International Organization 15: 366-92.

Haas, Ernst B. 1964. Beyond the Nation-State: Functionalism and International Organization. Stanford: Stanford University Press.

Haas, Ernst B. 1970. "The Study of Regional Integration: Reflections on the Joy and Anguish of Pretheorizing." In Regional Integration: Theory and Research, edited by Leon N. Lindberg and Stuart A. Scheingold. Cambridge: Harvard University Press, 3-42.

Hall and Sockice eds. 2001 Varieties of Capitalism: The Institutional Foundations of Comparative Advantage. Oxford: Oxford University Press, 2001.

Haesly, Richard. 2001. "Euroskeptics, Europhiles and Instrumental Europeans: European Attachment in Scotland and Wales.” European Union Politics 2: 81-102.

Herrmann, Richard, Marilynn Brewer, and Thomas Risse eds. 2004. Identities in Europe and the Institutions of the European Union. Lanham, Md.: Rowman and Littlefield.

Hix, Simon. 1999. "Dimensions and Alignments in European Union Politics: Cognitive Constraints and Partisan Responses." European Journal of Political Research 35: 69-106.

Hooghe, Liesbet and Gary Marks. 1996. "Birth of A Polity. Struggle for European Integration." Paper presented at the Tenth International Conference of Europeanists, Chicago, March 14-16. 
Hooghe, Liesbet and Gary Marks. 1999. "The Making of a Polity: The Struggle over European Integration." In Continuity and Change in Contemporary Capitalism, edited by Herbert Kitschelt, Peter Lange, Gary Marks and John Stephens. Cambridge: Cambridge University Press, 70-97.

Hooghe, Liesbet and Gary Marks. 2003. "Unraveling the Central State, But How? Types of Multi-Level Governance.” American Political Science Review 97: 233-43.

Hooghe, Liesbet and Gary Marks. 2004. "Calculation, Community and Cues: Public Opinion on European Integration." Unpublished paper.

Hooghe, Liesbet, Gary Marks, and Carole Wilson. 2002. "Does Left/Right Structure Party Positions on European Integration?” Comparative Political Studies 35: 965-989.

Hooghe, Liesbet. 2003. "Europe Divided? Elites vs. Public Opinion on European Integration." European Union Politics 4: 281-305.

Imig, Doug, and Sidney Tarrow, eds. 2001. Contentious Europeans: Protest and Politics in the New Europe. Lanham, MD.: Rowman and Littlefield.

Inglehart, Ronald. 1977. The Silent Revolution. Princeton: Princeton University Press.

Inglehart, Ronald. 1970. "Public Opinion and Regional Integration." In Regional Integration: Theory and Research, edited by Leon N. Lindberg and Stuart A. Scheingold. Cambridge: Harvard University Press, 160-191.

Kitschelt, Herbert, Zdenka Mansfeldova, Radoslaw Markowski, and Gabor Toka. 1999. Post Communist Party Systems: Competition, Representation, and Inter-Party Cooperation. Cambridge: Cambridge University Press.

Kitschelt, Herbert. 1995. "A Silent Revolution.” In Governing the New Europe, edited by Jack Hayward and Edward Page. Durham: Duke University Press.

Leibfried, Stephan and Paul Pierson eds. 1995. European Social Policy: Between Fragmentation and Integration. Washington, D.C.: Brookings Institution.

Lindberg, Leon N., and Stuart A. Scheingold eds. 1970. Regional Integration: Theory and Research. Cambridge: Harvard University Press.

Lipset, Seymour Martin, and Stein Rokkan. 1967. "Cleavage Structures, Party Systems and Voter Alignments: An Introduction." In Party Systems and Voter Alignments: Crossnational Perspectives, edited by Seymour M. Lipset and Stein Rokkan. New York: Free Press, 1-64.

Marks, Gary and Doug McAdam. 1996. "Social Movements and the Changing Structure of Political Opportunity in the European Union." In Governance in the European Union, edited by Gary Marks, Fritz Scharpf, Philippe Schmitter, and Wolfgang Streeck. London/ Thousand Oaks: Sage, 40-63.

Marks, Gary, Liesbet Hooghe, Moira Nelson, and Erica Edwards. 2004. "Mapping Party Support in a United Europe: All in The Family?" Unpublished paper.

Marks, Gary, Richard Haesly, and Heather Mbaye. 2002. "What Do Subnational Offices Think They Are Doing in Brussels?" Regional and Federal Studies 12: 1-23.

Marks, Gary and Marco Steenbergen, eds. 2004. European Integration and Political Conflict: Citizens, Parties, Groups. Cambridge: Cambridge University Press.

Mazey, Sonia and Jeremy Richardson. 2001. "Institutionalising Promiscuity: Commission/ Interest Group relations in the EU." In The Institutionalisation of Europe, edited by Alec 
Stone Sweet, Wayne Sandholtz and Neil Fligstein. Oxford: Oxford University Press, 7193.

Mitrany, David. 1948. "The Functional Approach to World Organization." International Affairs July.

Mitrany, David. 1965. "The Prospect of European Integration: Federal or Functional." Journal of Common Market Studies December 1965.

Mitrany, David. 1966. A Working Peace System. Chicago: Quadrangle books.

Moravcsik, Andrew. 1998. The Choice for Europe: Social Purpose and State Power from Messina to Maastricht. Ithaca, N.Y.: Cornell University Press.

Niedermayer, Oskar, and Richard Sinnott, eds. 1995. Public Opinion and Internationalized Governance. Oxford: Oxford University Press.

Nye, Joseph S. 1970. "Comparing Common Markets: A Revised Neo-Functionalist Model." In Regional Integration: Theory and Research, edited by Leon N. Lindberg and Stuart A. Scheingold. Cambridge: Harvard University Press, 192-231.

Offe, Claus. 2000. "The Democratic Welfare State in an Integrating Europe." In Democracy Beyond the State: The European Dilemma and the Emerging Global Order, edited by Louis W. Pauly and Michael Th. Greven. Lanham, MD: Rowman \& Littlefield, 63-90.

Olsen, Johan P. 2004. "Unity, Diversity, and Democratic Institutions. What can we learn from the European Union as a large-scale experiment in political organization and governing?" Arena, Working Papers, WP 04/13.

Pentland, Charles. 1975. "Functionalism and Theories of International Political Integration." In Functionalism: Theory and Practice in International Relations, edited by A.J.R. Groom and Paul Taylor. London: University of London Press, 9-24.

Pollack, Mark. 2000. "Blairism in Brussels: The Third Way in Europe Since Amsterdam." In The State of the European Union: Risks, Reform, Resistance, and Revival, edited by Maria Cowles and Michael Smith. Oxford: Oxford University Press, 266-291.

Pollack, Mark. 2003. The Engines of European Integration. Delegation, Agency, and Agenda Setting in the EU. Oxford: Oxford University Press.

Sandholtz, Wayne and Alec Stone Sweet eds. 1998. European Integration and Supranational Governance. Oxford: Oxford University Press.

Sbragia, Alberta. 1996. "Environmental Policy." In Policy-Making in the European Union, edited by Helen and William Wallace. Oxford: Oxford University Press, 235-255.

Scharpf, Fritz. 1996. "Negative and Positive Integration in the Political Economy of European Welfare States." In Governance in the European Union, edited by Gary Marks, Fritz Scharpf, Philippe Schmitter, and Wolfgang Streeck. London/ Thousand Oaks: Sage, 15-39.

Scharpf, Fritz. 1999. Governing in Europe: Effective and Democratic? Oxford: Oxford University Press.

Scharpf, Fritz. 2001. European Governance. Common Concerns vs. the Challenge of Diversity. Working Paper 01/6. Cologne: Max Planck Institute for the Study of Societies.

Schmitter Philippe C. 2003. "Neo-Neo-Functionalism: Déjà vu, all over again?” In European Integration Theory, edited by Antje Wiener and Thomas Diez. Oxford: OUP. 
Schmitter, Philippe C. 1969. "Three Neofunctional Hypotheses About International Integration.” International Organization 23:161-166.

Schmitter, Philippe C. 1970. "A Revised Theory of Regional Integration." International Organization 24: 836-868. Also published in Regional Integration: Theory and Research, edited by Leon N. Lindberg and Stuart A. Scheingold. 1970. Cambridge: Harvard University Press, 232-264.

Schmitter, Philippe C. 1992. "Interests, Powers and Functions: Emergent Properties and Unintended Consequences in the European Polity." Center for Advanced Study in the Behavioral Sciences (typescript).

Schmitter, Philippe C. 1996. "Examining the Present Euro-Polity with the Help of Past Theories." In Governance in the European Union edited by Gary Marks, Fritz Scharpf, Philippe Schmitter, and Wolfgang Streeck. London; Thousand Oaks: Sage, 121-50.

Schmitter, Philippe C. 2000. How to Democratize the Emerging Euro-Polity: Citizenship, Representation, Decision-Making. Boulder, Co.: Rowman \& Littlefield.

Stone Sweet, Alec, Wayne Sandholtz, and Neil Fligstein eds. 2001. The Institutionalization of Europe. Oxford: Oxford University Press.

Stråth, Bo, and Anna Triandafyllidou eds. 2003. Representations of Europe and the Nation in Current and Prospective Member States. The Collective State of the Art and Historical Reports. Brussels: European Commission, Directorate-General for Research, EUR 20736.

Streeck, Wolfgang, and Philippe Schmitter. 1991. "From National Corporatism to Transnational Pluralism: Organized Interests in the Single European Market." Politics and Society 19: 133-64.

Streeck, Wolfgang. 1996. "Neo-Voluntarism: A New European Social Policy Regime?" In Governance in the European Union, edited by Gary Marks, Fritz Scharpf, Philippe Schmitter, and Wolfgang Streeck. London/ Thousand Oaks: Sage, 64-94.

Taggart, Paul and Aleks Szczerbiak. 2004. "Contemporary Euroscepticism in the Systems of the European Union Candidate States of Central and Eastern Europe." European Journal of Political Research 43: 1-27.

Taggart, Paul. 1998. "A Touchstone of Dissent: Euroscepticism in Contemporary Western European Party Systems.” European Journal of Political Research 33: 363-388.

Taylor, Paul. 1975. "Functionalism and International Relations." In Functionalism: Theory and Practice in International Relations, edited by A.J.R. Groom and Paul Taylor. London: University of London Press, 1-7.

Tilly, Charles. 1990. Coercion, Capital, and European States, A.D. 990-1990. Oxford: Blackwell.

Van der Eijk, Cees and Mark Franklin eds. 1996. Choosing Europe? The European Electorate and National Politics in the Face of Union. Ann Arbor: University of Michigan Press.

Van Kersbergen, Kees. 2000. "Political Allegiance and European Integration." European Journal of Political Research 37: 1-17.

Wessels, Bernhard. 2004. "Contestation Potential of Interest Groups in the EU: Emergence, Structure, and Political Alliances." In European Integration and Political Conflict, edited by Gary Marks and Marco Steenbergen. Cambridge: Cambridge University Press, 195215. 